\title{
Специфика и характер деятельности передвижных учреждений культуры в Горном Алтае в 1920-1930-е годы
}

\begin{abstract}
Аннотаиия. Предметом исследования является культурно-просветительная деятельность передвижных учреждений - юрт-передвижек - в Горном Алтае в 1920-1930-е годы. Оббектом исследования является проиесс культурного развития Горного Алтая. Автор подробно рассматривает такие аспекты темы, как особенности создания и деятельность передвижных уиреждений культурь - юрт-передвижек, - действовавших в исследуемый период в Горном Алтае. Целью статьи является анализ изучения спечифики и характера деятельности передвижных уиреждений культуры в Горном Алтае в 1920-1930-е годы. Особое внимание уделено истории возникновения данного учреждения, выяснению его функиий и задач. В статъе рассмотренъ особенности работы юрт-передвижек в условиях кочевого образа жизни коренного населения. Основным методом исследования был системный анализ. Также данное исследование основано на приниипах историзма, объективизма, единства и взаимосвязи общего и особенного. Основными выводами проведенного исследования является доказательство того, что передвижная форма работы в условиях разбросанности и труднодоступности населенных пунктов и кочевого образа жизни алтайцев была наиболее пригодной и приспособленной для работь с населением Горного Алтая, приобщала его к ранее непривычному быту и способствовала поднятию его общего культурного уровня. Кроме того, данные учреждения проводили активную идеологическую работу, вели борьбу с традиционными религиозными верованиями и пропагандировали коммунистические идеалы. Использование автором различных источников, в том числе архивных, дало возможность более подробно изучить историю создания и специфику работы юрт-передвижек. Новизна исследования состоит в том, ито в нем впервые проведен комплексный анализ недостаточно исследованной ранее темы, введены в оборот новые понятия.
\end{abstract}

Ключевые слова: Горный Алтай, алтайчы, культурное преобразование, культурные учреждения, юрты-передвижки, кочевой образ жизни, передвижные учреждения, передвижное кино, народное образование, идеологическое воспитание.

Abstract. The article's research subject is the cultural and educational activity of mobile institutions - mobile yurts, in Gorny Altai in the 1920s-1930s. The research object is the process of Gorny Altai's cultural development. The author examines in detail such aspects of the topic as the particularities of the creation and work of these mobile cultural institutions (the mobile yurts) operating during the named period in Gorny Altai. The aim of the article is to analyse the study of the nature and specifics of the mobile cultural institutions' work in Gorny Altai in the 1920s-1930s. Particular attention is given to the history of the institutions' appearance and to elucidate its functions and tasks. The article clarifies the particularities of the mobile yurts' work under the conditions of the native population's nomadic way of life. The study's main research method is the systematic method. The research is also based on the principles of historicism, objectivity, unity and interrelation of the general and the particular. The main conclusion derived from the study is the ascertainment that the mobile form of work, under the conditions of sparseness and difficultness of access to the populated settlements and the nomadism of Altaians, was most suitable and fitting for work with the population of Gorny Altai. This mobile form of activity familiarised the population with the unfamiliar to it way of life and raised its general cultural standards. Additionally, these institution actively conducted ideological work, fighting against traditional prejudices and imposing communist ideals. The author's special contribution to the research of this topic is the use of different sources, including archival material, which have allowed to study the history of creating and of the specific of the mobile yurts' work. The novelty of this research consists in its complex analysis of the little-studied topic and introducing new concepts for scientific use.

Key words: Gorny Altai, Altaians, cultural transformation, cultural institutions, mobile yurts, Nomadic way of life, mobile institutions, mobile cinema, public education, ideological education. 
$\mathrm{H}$ а сегодняшний день особую важность представляет изучение культурных процессов происходивших в советский период. Начавшаяся с середины 1980-х годов активизация изучения отдельных вопросов в рамках историкоантропологического подхода в исследованиях способствовала активной постановке новых и ранее находящихся в тени исторических проблем. Наряду прочими моментами исследования стали посвящены естественным проблемам советских людей в жилье, продовольствие, медицине и культурном развитии.

После Октябрьской революции культура стала частью общепартийного дела, а ее развитие было полностью подчинено общим целям социалистического строительства. В нашем случае изучение данного вопроса предваряется понятиями «культурный фронт» и «культурная революция». В них отчетливо прослеживались задачи советского правительства по культурному преобразованию. В рамках первого понятия предполагалось поднятие культурного уровня населения, ликвидация его неграмотности и решение вопросов идеологического характера. Второе же раскрывало задачи по воспитанию нового типа личности на коммунистических идеалах. Реализацию этих общегосударственных задач можно проследить на примере отдельного региона, такого как Горный Алтай. Здесь можно выявить общие моменты, происходившие по всей стране и свою специфику.

Одной из мер в деле преобразования общества стало создание сети особых культурных учреждений: народных домов, клубов, библиотек, изб-читален и т.д. Эти учреждения активно работали и в Горном Алтае, но здесь создавались и свои особые учреждения. Их появление было вызвано географическими и этнокультурными особенностями данного региона, при которых обычным стационарным учреждениям работать было сложно, а порой и вовсе не реально.

Исторически вследствие процессов вхождения северной и южной территории Горного Алтая в состав России (1756 г. и 1864 г.) было сформировано три самых крупных мирно ужившихся на әтой территории этнических группы: коренные жители - алтайцы, русские и казахи. Для каждой из них были характерны собственные тенденции культурно-бытового, хозяйственного и демографического развития при том, что общими были труднодоступность горной местности, отдаленность от городов (уездного г. Бийска, губернского г. Томска) и железнодорожных транспортных путей. Имеющиеся пути сообщения в виде конных дорог связывали в основном большие и торговые села. Представляли они из себя в некоторых местах труднопроходимые перевалы и переправы через быстрые реки. Последние к тому же были взорваны во время гражданской войны по пути отступления по Чуйскому тракту в Монголию белогвардейских отрядов. В данных условиях еще ко всему основным занятием подавляющего числа алтайского и казахского населения оставалось кочевое скотоводство. Очень низкой была плотность населения и большая разбросанность населенных пунктов. Думаем, что многие из этих моментов не могли не сказаться на общем культурном развитии региона до революции, а затем затрудняли воплощение культурной программы большевикам.

Конечно, нельзя утверждать, что до установления советской власти культурной работы на Алтае не велось вообще, так как в этом вопросе очень преуспевала Алтайская духовная миссия, но своими силами и пожертвованиями. Работа миссии хоть и была успешной даже среди кочевого населения, все же имела религиозный отпечаток, что было чуждо советскому правительству. В новых условиях появления «культурного фронта» и провозглашения «культурной революции» требовалось провести огромную культурно-просветительную работу не только с русскими крестьянами, но и другими народами. В Горном Алтае эту работу затрудняли вышеуказанные особенности. Наряду с обычными культурными учреждениями они привели к созданию своеобразных передвижных учреждений способных решить поставленные задачи.

В исследовании внимание обращается главным образом на деятельность таких учреждений как - юрты-передвижки, работавшие в условиях бездорожья и разбросанности кочевого населения по горным урочищам. Данные учреждения имели алтайское название - кызыл-аилы (красные-юрты). Красные юрты являлись своеобразной комплексной формой культурно просветительной работы среди кочевого населения, а их работа в основном приходилась на конец лета и начало осени. В состав мобильной юрты помимо заведующего-юртача, входили массовик, киномеханик (при наличии кинопередвижки), инструктор-бытовик, медработник, зоотехник, избач (библиотекарь) и иногда баянист. Имелись палатки, музыкальные инструменты, библиоте- 


\section{Исторический журнал: научные исследования № 3 (33) • 2016}

DOI: $10.7256 / 2222-1972.2016 .3 .19385$

ка и многое другое. Кроме работы по агитации оседлого образа жизни среди кочевников позже они обслуживали колхозы и бригады пастухов вынужденных вести кочевки со стадами по отдаленным пастбищам Горного Алтая.

В целом перед кызыл-аилами ставилась задача стать «школой ученичества по преобразованию быта и условий жизни алтайцев». Юртыпередвижки представляли собой своеобразное сочетание избы-читальни и врачебно-консультационного пункта. Форма работы этих учреждений оказалась наиболее приспособленной к условиям, осложнявшим культурную деятельность и к жизненному укладу кочевников, а позже колхозных пастухов. В силу разбросанности населения, кочевого и полукочевого образа жизни значительной части алтайцев и недостатка культурно-пропагандистских работников в других учреждения культуры, было признано необходимым «шире практиковать опыт работы юртпередвижек» $[1]$.

Передвижки, добравшись до места, ставили войлочную палатку и оказывали населению медицинскую помощь, а так же проводили с ним санитарно-профилактическую и культурно-просветительную работу. Работники юртыпередвижки разъясняли национальную политику коммунистической партии и при этом вели борьбу с патриархально-родовыми предрассудками. В рамках политики перевода алтайцев к оседлости разъясняли плюсы оседлого образа жизни. Кочевникам объясняли вред для здоровья от задымленных юрт (аилов) в которых зимой было холодно. Организовывали кружки рукоделия, кулинарии и домоводства. Разъясняли так же пагубность для здоровья (особенно женщин) ряда привычек и традиций, таких как курение трубки и употребления молочного самогона (аракы). В течение летнего периода каждая передвижка должна была обслужить несколько урочищ. Работники этого учреждения в беседах и лекциях широко использовали кинофильмы, диафильмы, газеты, журналы и наглядные пособия. Юрты-передвижки уделяли большое внимание и работе среди женщин. Кочуя по урочищам, кроме общей санитарно-профилактической работы, они объясняли гигиенические правила ухода за детьми. Днем их работники проводили показательную уборку в алтайских юртах, мыли посуду, готовили пищу, а так же давали различного рода справки. Вечером проводили беседы, которые сопровождались показом диапозитивов, а иногда и демонстрацией кинофильмов.
Диафильмы и кинокартины вызывали особенно глубокий интерес среди населения. Большой популярностью пользовались световые газеты[2].

Если в составе работников юрты-передвижки был медик, то он осуществлял осмотр населения и жилищ, оказывал медицинскую помощь, консультировал и разъяснял необходимость обращения к врачу в случае болезни. Для осуществления просветительной работы в распоряжении юрты имелись комплекты художественной, политической и сельскохозяйственной литературы, швейные машины и патефоны[3].

Великой силой массовой идеологической и культурно-просветительной работы в то время стало кино. В Горном Алтае кинофикация получила развитие после создания на его территории в 1922 г. Ойротской автономной области. В регион поступили две киноустановки: стационарная и передвижная. Юрты-передвижки активно использовали кино в своей работе. Важное место в системе культурно-просветительной работы юрт-передвижек в 1920-1930-е годы среди алтайского населения занимали именно передвижные киноустановки. Кроме обычного показа фильмов направления деятельности передвижек были разнообразны, так как показы сопровождались беседами или лекциями [4].

О необходимости создании юрт-передвижек с киноустановками сообщалось в местной периодике. Так газета «Ойратский край 16 ноября 1923 г. писала: «Краевой Отдел Народного Образования решил широко развить работу по организации передвижек, в сельских местностях края считая работу кино средством культурного и политического воспитания населения. Так же была принята необходимость использования кино в практической работе для научной сельскохозяйственной и революционной пропаганды» [5].

Впервые кино в Ойротской автономной области было показано в 1924 г. В ее столице с. Улала (ныне г. Горно-Алтайск) показали картину «Первый вальс». Его появление взбудоражило население области. Летом этого же года кинопередвижку «Пате» с фильмом «На крыльях ввысь» и агитационный киножурнал закупил Уймонский аймачный (районный) исполнительный комитет. Но по просьбе руководителей других аймаков в пропагандистских целях юртапередвижка ехала туда окружным путем через аймачные села Улаган и Кош-Агач[6].

О работе этой юрты-передвижки с киноаппаратурой писала в сентябре 1925 г. газета «Ой- 
ратский край»: «В Улаганском, Кош-Агачском аймаках кино было впервые за все время их существования. Население этих аймаков встретило кино восторженно, приезжали за сотни верст - только бы «посмотреть живых людей». В течение 15 дней кино обслужило 8 пунктов: Ардыбаш, Кумуртук, Паспарта, Улаган, КошАгач, Курай, Чибит, Усть-Коксу, пропустив, из них $90 \%$ алтайцев[7]».

Обычно демонстрация нового фильма начиналась не с ближе всех расположенного от райцентра населенного пункта, а с самого дальнего. Это происходило в том случае, когда киномеханик на попутках добирался до райцентра за новой картиной. Во всем же остальном маршрут кинопередвижки выдерживался с таким расчетом, чтобы время, затраченное на переезды из одного села в другое не отражалось на выполнении финансового плана и на количество показа кинокартин[8].

Хотя деятельность юрт-передвижек была направлена в основном на работу с коренным населением. Они работали в тех аймаках Ойротской области, где преобладало алтайское население. Это были Онгудайский, Усть-Канский, УстьКоксинский, Улаганский и Кош-Агачский аймаки. Однако данные учреждения, обладая особой аппаратурой, затрагивали и другие районы. Так юрта-передвижка побывала в Лебедском аймаке, где преобладало русское население. А. Сатонин описал работу кинопередвижки в с. Кебезень, данного аймака следующим образом: «Приехала кинопередвижка. В школе битком набито народу. С нетерпением ждут «живых картинок» [...] После сеанса киномеханик вкратце объяснил устройство и работу аппарата. Впечатление от картины огромное» [9].

Значение таких мобильных учреждений культуры, использовавших в своей работе кино, осознавалась всеми руководителями аймаков, которые начали приобретать свои кинопередвижки. «Усть-Канские и Уймонские аймаки купили, Кош-Агачский и Онгудайский покупают передвижные киноаппараты», - сообщалось в газете «Ойратский край» 26 августа 1925 г. [10]

В 1925 г. в Горном Алтае на 5 национальных аймаков было всего 3 юрты-передвижки, но их деятельность дала особый результат, после чего в следующем году работало уже 5, а в 1927 г. 11 юрт-передвижек[11].

Несмотря на большую популярность и значение в работе юрт-передвижек кино, по мнению селькора И. Лудикова наблюдался ряд недостатков: «Их много. Основными являются пассивное отношение в некоторых деревнях к кинопередвижкам со стороны сельских Советов. Зачастую не оказывают содействия следить за порядком во время сеанса. Зрители проходят бесплатно. Ломают иногда даже двери. Не извещают своевременно население о прибытии кинопередвижки и т.п. Также нужно отметить и недостаток кинокартин, или картины присылают не во время, особенно когда их высылают в летнее время, когда население занято полевыми работами» [12].

Не смотря на некоторые минусы в большей части алтайских урочищ «Живые картины» вызывали резонанс, но опять же не везде положительный. Показательны в этом отношении стали «вести с мест», часто рассказывающие о работе кинопередвижек по аймакам области. Так тот же корреспондент Лудиков в другой статье вновь критиковал работу кинопередвижек: «В Уймонском аймаке за год продемонстрировано только семь кинокартин. Это влечет дефицит для кинопередвижки. У населения запрос большой, поэтому нужно наладить регулярное снабжение кинопередвижек картинами». Другой сельский корреспондент Кузин из Шебалинского аймака сообщал о картинах не интересных для крестьян: «Васька больничный сторож» драма в трех частях совершенно не интересует зрителей. Картина «На все времена, для всех народов» не особенно понятна для масс. Картину «Преступление коновала Матова», обрисовывающую жизнь деревни, зритель смотрит не внимательно, так как лента порвана» [13].

Кроме пробелов в работе кино были проблемы и с кадрами юрт-передвижек. Стоит отметить, что ни первое, ни второе не зависело от их самих. Для передвижек требовались грамотные заведующие, знающие алтайский язык, но таких было мало. Имеющиеся подходящие кадры вынуждены были совмещать свою деятельность. В 1928 г. руководителем культурно-просветительной передвижки под названием «Красная юрта» был знаменитый алтайский писатель Павел Васильевич Кучияк[14]. Его просветительно-пропагандистская деятельность в лице юртача была успешной, но в виду совмещения была неудобной, так как приходилось покидать передвижку в разгар ее работы и отправляться на слеты писателей или по партийным заданиям.

Несмотря на указанные проблемы в целом передвижки выполняли болышой объем работы. Так в 1928 г. заведующий юртой-передвижкой 


\section{Исторический журнал: научные исследования № 3 (33) • 2016}

DOI: $10.7256 / 2222-1972.2016 .3 .19385$

по Усть-Канскому аймаку сообщал в докладе: «... двадцатого июня юрта-передвижка с кинооператором, выставкой... направилась к самым глухим урочищам аймака. Юртой только с 11 по 17 сентября обслужено 8 сельсоветов, в них 18 урочищ и аймачный центр с близлежащими урочищами. По урочищам охвачено 1601 человек: мужчин 1138, женщин - 463, а по самому Усть-Кану 440 мужчин и 394 женщины» [15].

О налаживании юрты-передвижки с киноаппаратурой в Усть-Канском аймаке говорилось в докладе от 17 сентября 1929 г. заведующего этой передвижкой Маркина: «[...] Из Москвы все оборудование юрты было отправлено в Ойротию 1 июля, работники выехали 3 июля. Заведующий юртой прибыл в областной центр 11 июля [...] На совещании при Областном Отделе Народного образования от 16 июля было постановлено и утверждено Облисполкомом направить юрту-передвижку и передвижную консультацию отдела материнства и младенчества народного комиссара здравоохранения в УстьКанский аймак. Для областного слета пионеров в Улале был продемонстрирован фильм «Водоворот», и 5 августа юрта выехала в Усть-Кан. По дороге в урочище Соузга после собрания были продемонстрированы фильмы при присутствии 130 чел., и 10 августа юрта прибыла в Усть-Кан. Согласовали план работы с аймачной партийной организацией, аймакисполкомом и с передвижной консультацией охраны материнства и младенчества. 12 августа юрта-передвижка с киноаппаратом и выставкой по народному хозяйству направилась по самым глухим урочищам аймака».

Так же с 15 по18 августа 1929 г. было обслужено постановками кино, кукольным театром, выставкой и радио аймачная батрацкая конференция и население с. Усть-Кан с прилегающими к нему ближайшими урочищами. Основная работа юрты была с киноаппаратом и выставкой по народному хозяйству. Днем велась разъяснительная работа по пятилетке и по займу индустриализации, а вечером была работа с картинами, которые разъяснялись сразу во время их демонстрации. Первым средством привлечения к юрте-передвижке была гармошка, которую большинство алтайцев до этого не слышали. Всего из 9986 человек живших в аймаке было обслужено 2440 человек[16].

Как только передвижка приезжала в урочище сразу же приколачивали экран. После просмотра кинокартин многие говорили, что они не знали, что будет так, а поэтому и не все пришли. «Если нам будут так показывать и разъяснять - это самая хорошая для нас школа, не надо ездить в село или город для того, чтобы посмотреть, как живут русские люди», - делились своими впечатлениями алтайцы. Население было заинтересовано не только кинокартинами, но и разъяснениями по вопросам народного хозяйства и проведения национальной политики советской властью[17].

В газете «Ойротский край» 1 января 1930 г. сообщалось о планах открытия новых передвижек: «Нынче в разных колхозах области будет открыто [...] 3 кинопередвижки [... ] через [...] кино коллективисты получат возможность поднимать свою культурность [...]»[18]. В дальнейшем все же по мере постепенного перехода алтайцев на оседлость значение юрт-передвижек начало снижаться [19].

В 1931 г. юрта-передвижка из Усть-Канского аймака организовала 4 бытовых секции в 20 населенных пунктах и провела показательную стирку белья, мытья посуды и уборку жилища. Кроме того она организовала медицинский осмотр и оказала медицинскую помощь 1500 человек. С апреля 1931 г. красные-юрты были закреплены за конкретными аймаками: первая работала в Улаганском и Кош-Агачском аймаках, вторая в Онгудайском, третья - в Усть-Канском и четвертая - в Лебедском аймаках. Юрта-передвижка обслуживающая первые два аймака была самой крупной и хорошо оборудованной, поскольку на ее базе в последующем планировалось организовать стационарное культурное учреждение Дом алтайки. В целом обретение оборудования для передвижек в 1931 г. обошлось области в 37 тысяч рублей, учитывая, что данные учреждения функционировали всего четыре месяца в год - с мая по август. Заметим, что сеть юртпередвижек до 1931 г. постоянно росла (1927 г. 11 , в 1930 г. - 18), а затем она стала заметно сокращаться (к 1936 г. - 4), что это было связано с достигнутыми успехами по переходу основной массы алтайского населения к оседлому образу жизни. В связи с этим стало возможным создание при крупных колхозах и аймачных центрах домов культуры. К 1936 г. было оставлено всего 4 юрты-передвижки для обслуживания наиболее отдаленных от культурных центров колхозов. Однако объем работы передвижек в это время оставался на высоком уровне. Так Усть-Канской юртой-передвижкой за довольно короткое время в 13 колхозах аймака были организованы 
бригады по сенокошению, заключено 27 договоров по социальному соревнованию, оказана помощь в налаживании работы 6 детских яслей и обучены шитью 23 алтайки[20].

Из художественных фильмов, которые демонстрировали передвижки, самыми популярными среди алтайцев были «Броненосец Потемкин», «Стачка», «Мать», «Конец СанктПетербурга» и др. Киноискусство в 1930-е гг. попрежнему было в зоне повышенного внимания властей, поскольку отличалось быстрым и прочным воздействием на сознание людей. В 1931 г. вышло Постановление ЦК ВКП (б) «О советской кинематографии», определившее ход развития советского кино на многие годы. «Задача советского кино, говорилось в Постановлении, - заключается в том, чтобы создать кинокартины такого качества, чтобы обеспечить стремление [...] получить от кино развлечение, отдых, поднятие своего культурного и политического уровня [...] В соответствии с этим и должно определяться содержание кинокартин»[21].

В 1932 г. был немного изменен штат юртпередвижек в связи с новыми хозяйственно-политическими задачами. В ее состав входили заведующий юртой-алтаец или так называемый юртач, врач, фельдшер-акушерка, инструкторбытовик и практикантка-алтайка. Заведующий юртой должен был работать каждый день по пять часов. С целью поднятия своего культурно-политического уровня юртачи должны были ежедневно прочитывать руководящие периодические издания и иметь представления о мероприятиях сельсоветов, колхозов и совхозов. Широкое развитие в это время получило хроникально-документальное кино, пришедшее на смену агитационно-пропагандистским фильмам, выпуск которых прекратился с 1933 г.[22]. Популярная в массах кинохроника пропагандировала опыт передовиков и новаторов социалистического соревнования и рассказывала о положении дел на стройках первых пятилеток.

В условиях снижения числа юртпередвижек и повышенным вниманием к кино общее количество киноустановок в аймаках Ойротской области было недостаточным. Так, например на весь Кош-Агачский аймак в 1931 г. имелась всего одна кинопередвижка. Такая же ситуация была в Улаганском и Усть-Канском аймаках. Лишь Онгудайский аймак располагал двумя кинопередвижками. И только к 1938 г. областной центр (к тому времени переименованный в г. Ойрот-Тура) располагал шестью киноустановками [23].

В условиях коллективизации юртам-передвижкам принадлежало оставаться так же одно из важных мест в работе среди женщин. О них шел разговор на областном расширенном совещании заведующих аймачными женскими секторами и сельских органов в Горном Алтае 2 ноября 1931 г. Обсуждались как положительные, так и отрицательные стороны деятельности юрт-передвижек в области охраны материнства и детства. Например, в усть-канской юрте работал мужчина. Алтайки его боялись, поэтому сложно было найти взаимопонимание и вызвать заинтересованность. IV пленум Ойротского областного комитета ВКП (б) отмечал в 1933 г., что в новых колхозах улучшается быт женщин. Но в отдаленных районах еще не все женщины обращаются в больницу (Улаган и Кош-Агач). Для повышения эффективности медпомощи в этих районах областной комитет партии решил послать специализированную юрту-передвижку и особо обратить внимание на подготовку женщин-алтаек для работы среди местного населения и на санитарное просвещение. В 1934 г. кош-агачской юртой-передвижкой работавшей с 20 июня по 1 августа, было обслужено 8 аймаков. Проведено 13 бесед на темы: «Гигиена жилища», «Сибирская язва», «Задачи охраны материнства и детства» и «Санитарный минимум в яслях». Более того было хвачено беседами 158 женщин, принято 188 больных и проведен медицинский осмотр 330 школьников и доярок. 14 женщин посетили показательный урок по уходу за детьми. На местах было выбрано 8 санитарных постов и осмотрено 5 молочных ферм. Беседы проводились с помощью переводчика, который оживлял медицинский материал жизненными примерами[24].

В 1935 г. юрта-передвижка Кош-Агачского аймака во главе с Аргоковой объехала 17 колхозов и побывала в самых отдаленных и труднопроходимых высокогорных местах аймака, таких как Джазаторский сельский совет. В составе передвижки были инструктор-бытовик, пропагандист, врач, зоотехник, баянист и киномеханик. Они верхом на лошадях проехали в труднодоступные стойбища пастухов. Ими были проведены медосмотры и оказана медицинская помощь, а для молодых матерей проведены практические занятия по уходу за детьми. Эта деятельность кош-агачской юртыпередвижки в 1936 г. так же освещалась на страницах местной периодики. Так, в газете «Красная Ойротия» говорилось: «Юрта-передвижка, кото- 


\section{Исторический журнал: научные исследования № 3 (33) • 2016}

DOI: $10.7256 / 2222-1972.2016 .3 .19385$

рой руководит член партии товарищ Аргокова, с июля по декабрь 1935 г. объехала 17 колхозов аймака [...] В оборудование юрты было два патефона, швейная машинка, аптечка, кинопередвижка и баян» [25].

В 1938 г. определяя успехи юрт-передвижек, местные органы власти не смогли увидеть перспективу их дальнейшего использования. В условиях перехода на оседлость органы государственной власти приняли решение отказаться от передвижных форм работы, сосредоточив свое внимание на создании стационарных Домов алтайки, которые должны были знакомить женщин с элементарными навыками санитарии и гигиены, домоводства, огородничества и ухода за детьми. Те задачи, которые выполнили кызыл-аилы в 1920-1930-е гг., были решены. В начале третьей пятилетки, в Ойротской области оставили всего лишь 2 юрты-передвижки.
Таким, образом, род деятельности юртпередвижек был разнообразен, от оказания медицинской помощи и санитарно-профилактической работы до культурно-просветительной работы. Передвижная форма работы, в условиях разбросанности и труднодоступности населенных пунктов и кочевого образа жизни алтайцев, была наиболее пригодной и приспособленной для работы с населением Горного Алтая, приобщением его к ранее непривычному быту и поднятие его общего культурного уровня. Кроме того данное учреждение проводило активную идеологическую работу, борьбу с традиционными предрассудками и навязыванием коммунистических идеалов. Юрты-передвижки активно действовали до середины 1930-х годов, но впоследствии, в связи с переходом основной массы алтайского населения на оседлый образ жизни, необходимость в них отпала.

\section{Библиография:}

1. Демидов В. А. Краеведческий материал по истории Горно-Алтайской автономной области. Горно-Алтайское книжное издательство. Горно-Алтайск, 1962. С. 57.

2. Потапов Л. П. Очерки по истории Горно-Алтайской автономной области. Горно-Алтайск: Горно-Алтайское отделение Алтайского книжного издательства, 1973. С. 338-339.

3. Денчик Н. П. Особенности культуры и быта алтайской деревни в 20-е гг. ХХ в. // Алтайская деревня: история, современное состояние, перспективы развития. Сборник докладов, сообщений. Горно-Алтайск: РИО «Универ - Принт», 2004. С. 62.

4. Екеева Н. М. История Горного Алтая в 3-х т. Т. 2. 1900-1945 гг. / Под ред. Н.М. Екеевой, Н. Ф. Иванцовой. Бийск: Типография Бийского государственного педагогического института, 2000. С. 246.

5. Кино для крестьян. // Ойратский край. 1923 г. №14.

6. Улала, Ойрот-Тура, Горно-Алтайск. Страницы истории. Летопись города с 1830 по 1945 годы / Под ред. А.В. Эдокова. Горно-Алтайск, 1997. С. 57-58.

7. Остроумова В. Отрадные вести. Кино-передвижка по Области // Ойратский край. 1925. № 61(159). С. 76.

8. Угрюмов В. П. Сельский киномеханик. Горно-Алтайск: Горно-Алтайское книжное издательство, 1958. С. 8-9.

9. Государственный архив социально-правовой документации Республики Алтай (ГАСПД РА). Ф.68. Оп1. Д. 205. Л 67.

10. Калина И. Кино-передвижка. Маленький фельетон // Ойратский край. 1925. № 51(149). С. 98.

11. Гончарова О. А. Горный Алтай: история народной медицины и здравоохранения. Томск: Изд-во Том. ун-та, 2008. С. 96.

12. Лудиков И. С кино-передвижкой по деревне // Ойротский край. 1927. 19 февраля. С. 8.

13. Ойротский край. 1927. 2 февраля.

14. Республика Алтай. Краткая энциклопедия. Новосибирск: Изд-во «Арта», 2010. С. 194.

15. Захарова Т. В. Из истории становления советской культуры в Горном Алтае // Мир Евразии. ГАГУ, 2009. № 3(6). С. 41-42.

16. Судьбы коренных народов Горного Алтая (Из истории национально-государственного строительства. 1800 - 1940 гг.). Сборник документов / под ред. Н. С. Модорова. - Горно-Алтайск, 2004. С. 213.

17. Бородкин П. А. Культурное строительство на Алтае. 1917 - 1941 гг. / П.А. Бородкин [и др.]; отв. ред. А.Н. Невский. Документы и материалы. Барнаул, Алт. кн. издательство, 1980. С. 231.

18. Избы-читальни, радио, ясли - в колхозы. // Ойротский край. 1930. № 5(574).

19. Модоров Н. С. История и Культура Горного Алтая. Уч. пособие. Горно-Алтайск, 1992. С. 118.

20. Захарова Т. В.Поиск эффективных форм и методов работы среди женщин в 1930-е годы (На материалах Горного Алтая) // История и культура народов Юго-Западной Сибири и современных регионов (Казахстан, Монголия, Китай): материалы Международной научно-практической конференции. Горно-Алтайск, Республика Алтай, Российская Федерация, 25-26 мая 2010 г. Горно-Алтайск: РИО ГАГУ, 2010. С. С. 24.

21. КПСС в резолюциях и решениях съездов, конференций и пленумов ЦК (1898-1986). Т. 4. 1926 - 1929. М.: Политиздат, 1984. С. 371.

22. Советская культура в реконструктивный период. 1928-1941 гг. М., 1988. С. 344.

23. ГАСПД РА. Ф. Р-61. ОП. 1. Д. 484. Л. 1.

24. Гончарова О. А. История становления системы здравоохранения национальных районов юга Сибири в 1920-1941 гг. / О. А. Гончарова. Томск: Изд-во Том. ун-та, 1995. С. 71-72.

25. История Горного Алтая. Часть 2. Горный Алтай в 1917-1940 гг. / Сост. О.А. Гончарова, Н.М. Екеева, Н.Ф. Иванцова, Н.А. Майдурова, Н.Р. Штанакова. Горно-Алтайск, 1995. С. 81. 


\section{References (transliterated):}

1. Demidov V. A. Kraevedcheskii material po istorii Gorno-Altaiskoi avtonomnoi oblasti. Gorno-Altaiskoe knizhnoe izdatel'stvo. Gorno-Altaisk, 1962. C. 57.

2. Potapov L. P. Ocherki po istorii Gorno-Altaiskoi avtonomnoi oblasti. Gorno-Altaisk: Gorno-Altaiskoe otdelenie Altaiskogo knizhnogo izdatel'stva, 1973. S. 338-339.

3. Denchik N. P. Osobennosti kul'tury i byta altaiskoi derevni v 20-e gg. XX v. // Altaiskaya derevnya: istoriya, sovremennoe sostoyanie, perspektivy razvitiya. Sbornik dokladov, soobshchenii. Gorno-Altaisk: RIO «Univer - Print», 2004. S. 62.

4. Ekeeva N. M. Istoriya Gornogo Altaya v 3-kh t. T. 2. 1900-1945 gg. / Pod red. N.M. Ekeevoi, N. F. Ivantsovoi. Biisk: Tipografiya Biiskogo gosudarstvennogo pedagogicheskogo instituta, 2000. S. 246.

5. Kino dlya krest'yan. // Oiratskii krai. 1923 g. №14.

6. Ulala, Oirot-Tura, Gorno-Altaisk. Stranitsy istorii. Letopis' goroda s 1830 po 1945 gody / Pod red. A.V. Edokova. Gorno-Altaisk, 1997. C. 57-58.

7. Ostroumova V. Otradnye vesti. Kino-peredvizhka po Oblasti // Oiratskii krai. 1925. № 61(159). S. 76.

8. Ugryumov V. P. Sel'skii kinomekhanik. Gorno-Altaisk: Gorno-Altaiskoe knizhnoe izdatel'stvo, 1958. C. 8-9.

9. Gosudarstvennyi arkhiv sotsial'no-pravovoi dokumentatsii Respubliki Altai (GASPD RA). F.68. Op1. D. 205. L 67.

10. Kalina I. Kino-peredvizhka. Malen'kii fel'eton // Oiratskii krai. 1925. № 51(149). S. 98.

11. Goncharova O. A. Gornyi Altai: istoriya narodnoi meditsiny i zdravookhraneniya. Tomsk: Izd-vo Tom. un-ta, 2008. S. 96.

12. Ludikov I. S kino-peredvizhkoi po derevne // Oirotskii krai. 1927. 19 fevralya. S. 8.

13. Oirotskii krai. 1927. 2 fevralya.

14. Respublika Altai. Kratkaya entsiklopediya. Novosibirsk: Izd-vo «Arta», 2010. S. 194.

15. Zakharova T. V. Iz istorii stanovleniya sovetskoi kul'tury v Gornom Altae // Mir Evrazii. GAGU, 2009. № 3(6). S. 41-42.

16. Sud'by korennykh narodov Gornogo Altaya (Iz istorii natsional'no-gosudarstvennogo stroitel'stva. 1800 - 1940 gg.). Sbornik dokumentov / pod red. N. S. Modorova. - Gorno-Altaisk, 2004. S. 213.

17. Borodkin P. A. Kul'turnoe stroitel'stvo na Altae. 1917 - 1941 gg. / P.A. Borodkin [i dr.]; otv. red. A.N. Nevskii. Dokumenty i materialy. Barnaul, Alt. kn. izdatel'stvo, 1980. C. 231.

18. Izby-chital'ni, radio, yasli - v kolkhozy. // Oirotskii krai. 1930. № 5(574).

19. Modorov N. S. Istoriya i Kul'tura Gornogo Altaya. Uch. posobie. Gorno-Altaisk, 1992. S. 118.

20. Zakharova T. V. Poisk effektivnykh form i metodov raboty sredi zhenshchin v 1930-e gody (Na materialakh Gornogo Altaya) // Istoriya i kul'tura narodov Yugo-Zapadnoi Sibiri i sovremennykh regionov (Kazakhstan, Mongoliya, Kitai): materialy Mezhdunarodnoi nauchno-prakticheskoi konferentsii. Gorno-Altaisk, Respublika Altai, Rossiiskaya Federatsiya, 25-26 maya 2010 g. Gorno-Altaisk: RIO GAGU, 2010. C. S. 24.

21. KPSS v rezolyutsiyakh i resheniyakh s"ezdov, konferentsii i plenumov TsK (1898-1986). T. 4. 1926 - 1929. M.: Politizdat, 1984. C. 371.

22. Sovetskaya kul'tura v rekonstruktivnyi period. 1928-1941 gg. M., 1988. C. 344.

23. GASPD RA. F. R-61. Op. 1. D. 484. L. 1.

24. Goncharova O. A. Istoriya stanovleniya sistemy zdravookhraneniya natsional'nykh raionov yuga Sibiri v 1920-1941 gg. / O. A. Goncharova. Tomsk: Izd-vo Tom. un-ta, 1995. S. 71-72.

25. Istoriya Gornogo Altaya. Chast' 2. Gornyi Altai v 1917-1940 gg. / Sost. O.A. Goncharova, N.M. Ekeeva, N.F. Ivantsova, N.A. Maidurova, N.R. Shtanakova. Gorno-Altaisk, 1995. S. 81. 